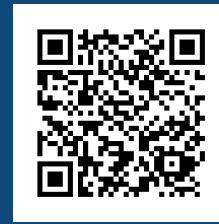

Keywords:

Charcoal

Gases

Macro ATG oven

Wood energy

Historic:

Received 27/04/2018 Accepted 10/09/2018

Correspondence: eng-marcia@hotmail.com
Marcia Silva Jesus ${ }^{1+}$, Alfredo Napoli', Paulo Fernando Trugilho', Áureo A. Abreu Júnior', Clara Lisseth Mendoza Martinez', Thaís Pereira Freitas'

\section{ENERGY AND MASS BALANCE IN THE PYROLYSIS PROCESS OF Eucalyptus WOOD}

JESUS, M.; NAPOLI, A.; TRUGILHO, P. F; ABREU JÚNIOR, A. A.; MARTINEZ, C. L. M.; FREITAS, T. P. Energy and mass balance in the pyrolysis process of eucalyptus wood. CERNE, v. 24, n. 3, p. 288-294, 2018.

\section{HIGHLIGHTS}

The process was carried out using an innovative pyrolysis technology, the Macro ATG oven.

Moisture contents ( 0.83 and I3\%) have a low influenced the charcoal yields.

The gas peak begins 120 minutes after pyrolysis ignition, this is the best period for burning gases.

$53 \%$ of the total energy of the process was concentrated in the charcoal.

\section{ABSTRACT}

The aim of this study was to evaluate the effect of the moisture content in the mass and energy balance of Eucalyptus wood during the pyrolysis process in a macro-lab scale. Two cylindrical specimens of $30 \mathrm{~cm}$ length, $12 \mathrm{~cm}$ diameter, and two pre-established moisture contents of $0.83 \%$ and $13 \%$, were evaluated. The experiment was carried out in an electric oven, heating rate of $5^{\circ} \mathrm{C} \cdot \mathrm{min}^{-1}$ and final temperature of $500 \circ \mathrm{C}$ were the process conditions. Mass and energetic potentials of the non-condensable gases flow, were estimated from the data provided by the software Macro Thermogravimetric. The moisture content did not influence significantly in charcoal yields (30.2 e 30.4\%). The highest energetic value of the non-condensable gases $(2.549 \mathrm{MJ})$ during wood pyrolysis at $0.83 \%$ moisture content, was achieve. Water presence on wood decrease the concentration of the energetic compounds. The total energy concentrated in the charcoal and sub-products was $53 \%$ and $47 \%$, respectively. The significant amount of sub-products suggests to consider the mass balance and flow energy compounds in further researches for integration and optimization technologies in both, production and gas burning processes, aiming to generate new industrial mechanisms to improve yield and quality of the products. 


\section{INTRODUCTION}

One of the main current days challenges is the climate change, which arises from the intensification of global warming. Greenhouse gas emissions from anthropogenic activities, such as the energy production of fossil fuels, are negatively impacting in climate changes worldwide. The search and insertion of renewable fuel sources, considering large-scale productions, is a strong opportunity for increase the potential of alternative sustainable energies such as biomass.

Considering the energetic global matrix, big amount of renewable energy sources come from biomass, which contributes to a significant demand of renewable and natural resources. According to the International Energy Agency (2017), it is estimated that about $10 \%$ of the world energy supply comes from biomass and derivatives.

The energy produced through biomass conversion can be achieve using diverse process parameters in different technologies. In addition, the evolution and expansion of industries which can integrate those systems, processes and products are growing and optimizing their management.

In Brazil, biomass energy sources are typically available and reliable from forest plantations, both renewable and natural can be used in several productive segments, such as paper and pulp industry, wood panel, and siderurgy. There are 7.8 million hectares of planted forests, $14 \%$ are designed to produce charcoal that feeds national siderurgy sector (Ibá, 2016). Brazil is also responsible for $14.9 \%$ of the world charcoal production, and it is the biggest producer in this category (Fao, 20I3).

In most of the Brazilian industries of charcoal, the most common thermochemical transformation of wood is a slow pyrolysis process. It works as a pre-step of carbon concentration regarding high energetic density. Moreover, industries are still employing low-tech level techniques, which generates low energetic efficiency considering the whole process. In the pyrolysis process of wood, it is assumed that $50 \%$ of the energy output is concentrated in the charcoal and the other half, in the sub-products, which are not fully used in the final system. In addition, $47 \%$ of the total energy available is lost during the pyrolysis performed in industrial charcoal kilns, meaning that just $53 \%$ of the initial energy is recovered during the process (Barcellos et al., 2004)

Theoretically and in laboratory experiments, it is possible to obtain during the carbonization: $30 \%$ of liquid, $35 \%$ of gases and $35 \%$ of charcoal. However, the optimization of these processes is totally related to the used technologies in the production system (Ernsting, 20I5).
Charcoal production in Brazil is widely performed in brick kilns. They are popular denominated as "rabo quente", with cylindrical or rectangular size, and without automated systems, this condition difficult the control of the pyrolysis process. According to Pereira et al. (20II), most of the technologies employed in this country are performed in type kilns. Charcoal production has low gravimetric yields and high emissions of polluting gases to the environment. Also, the process of burning gases is poorly used in these energy production sectors because of the unfamiliarity with its physical, kinetic and structural implication.

Indeed, the importance of improve the knowledge of the thermal conversion process progress of wood into charcoal is essential for the future energy researches. Likewise, the measure of the total energetic losses during the process will help to indicate the efficiency of the technologies. Hence, for a better approach of the experiments with the real behavior would be employ bigger wood specimens, not just in granulometric scales, since it is known that the Brazilian charcoal industry uses up to 3-meter logs in industrial charcoal kilns with a full capacity of burning $530 \mathrm{~m}^{3}$ of wood.

Therefore, this study aimed to evaluate the mass and energy balance of Eucalyptus urophylla wood in two different moisture contents during the macro-lab scale of the pyrolysis process, regarding a closer simulation of its respective industrial behavior.

\section{MATERIAL AND METHODS}

\section{Biomass and specimen preparation}

Two cylindrical wood samples of $30 \mathrm{~cm}$ of length and $12 \mathrm{~cm}$ in diameter of Eucalyptus urophylla clones with six years old, were used. Before the analysis, the samples were drying, one in an oven and the other in an acclimatized chamber until they reach the pre-established moisture content of 0.83 e 13\%, respectively.

\section{Pyrolysis process}

In the pyrolysis, it was used a Macro ATG oven (Figure I), developed by the Center for International Cooperation in Agronomic Research for Development CIRAD (France) in partnership with the Federal University of Lavras - UFLA (Brazil). This equipment is a prototype of a vertical electric oven with a pyrolysis reactor and load cell connected to a pyroligneous liquid condenser. A gas chromatograph flow meter (490 Micro GC) is coupled to the oven, which chemically identify gases emissions in real-time during the process. The system also allows temperature control, setting heating rate and gas flow vectors. All the process can be checked in the control panel and monitored by a Macro Thermogravimetric software. 


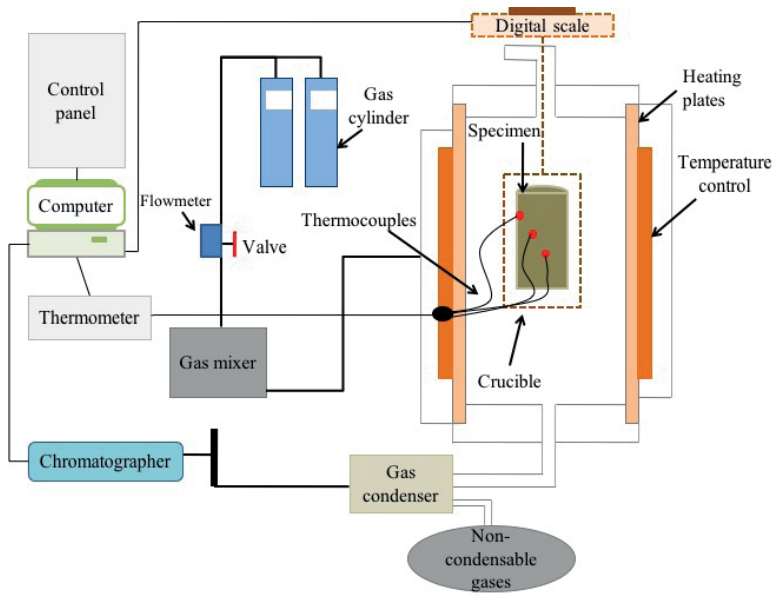

FIGURE I Design of Macro ATG oven plant.

\section{Pyrolysis conditions}

Wood pyrolysis was performed in a nitrogen $\left(\mathrm{N}_{2}\right)$ gas atmosphere; gas flow of 2,5 NL· $\mathrm{min}^{-1}$ (Normal $\left.\mathrm{Lt} \cdot \mathrm{min}^{-1}\right)$, heating rate of $5^{\circ} \mathrm{C} \cdot \mathrm{min}^{-1}$, and final temperature of $500^{\circ} \mathrm{C}$ with a residence time of $3 \mathrm{~h}$ in the highest temperature. Simultaneously, gases emissions were analyzed. In addition, a macro thermogravimetric profile during the thermal decomposition, was recorded.

Mass and energy balance

Wood pyrolysis, charcoal and pyroligneous liquid yields were calculated according to the dry mass of the wood samples. Non-condensable gases (NCG) yield was acquired by two means: one following the subtraction between the charcoal mass yield and condensable gases, considering a total of $100 \%$; and after total gases flow, in which all data were collected by the Macro Thermogravimetric software and estimated by the equations shown in the I to 4 (total gases flow $\left(\mathrm{NL} \cdot \mathrm{s}^{-1}\right)$ ), 5 (individual flow of gaseous compounds: $\mathrm{M}_{2}, \mathrm{CH}_{4}, \mathrm{CO}$, $\mathrm{CO}_{2}, \mathrm{C}_{2} \mathrm{M}_{4}$ e $\mathrm{C}_{2} \mathrm{H}_{6}\left(\mathrm{NL} \cdot \mathrm{s}^{-\mathrm{I}}\right.$ )), and 6 (Individual flow of gaseous compounds: $\mathrm{H}_{2}, \mathrm{CH}_{4}, \mathrm{CO}, \mathrm{CO}_{2}, \mathrm{C}_{2} \mathrm{H}_{4}$ and $\mathrm{C}_{2} \mathrm{H}_{6}$ $\left(\mathrm{NL} \cdot \mathrm{s}^{-1}\right)$, where: $\mathrm{Ft}$ : total gaseous flow, $F_{p_{i}}$ gaseous flow of pyrolysis, $F_{A r}$ : air flow inside the oven, $F_{N 2}$ : nitrogen gaseous flow inside the oven $\left(\mathrm{NL} \cdot \mathrm{s}^{-1}\right), \% \mathrm{O}_{2}^{\text {Ar: }}$ : oxygen percentage in the air $(78,08 \%), \% \mathrm{O}_{2}^{\top}$ : total percentage of infiltrated oxygen during the process, $\% \mathrm{~N}_{2}{ }^{\top}$ : total percentage of nitrogen in the process, $\mathrm{F}_{\mathrm{N} 2} \mathrm{C}$ : nitrogen gas flow from cylinder, \% $\mathrm{N}_{2}$ : percentage of nitrogen from cylinder (100\%), \% $\mathrm{N}_{2}{ }^{\text {Ar }}$ : percentage of nitrogen from air $\left.(20,95 \%), F_{k c}\right)$ : individual gaseous flow of each gaseous compound, $\% l_{c c}$ individual percentage of each gaseous compound, $M_{i G s}$ : individual mass of each gaseous compound, $V$ : individual volume of each gaseous compound $(L), M_{m i}$ : molar mass of each compound $\left(\mathrm{g} \cdot \mathrm{mol}^{-1}\right)$.

$$
\begin{aligned}
& F_{T}=F_{(P i)}+F_{(A r r)}+F_{\left(N_{2}\right)} \\
& F_{A r}=\frac{\left(F_{T} * \% O_{2}^{T}\right)}{\left(\% O_{2} A r\right)} \\
& F_{T}=\frac{\left(F_{N_{2}}{ }^{C * \%\left(N_{2}{ }^{C}\right)}\right.}{\left(\% N_{2}{ }^{T}-\% N_{2} * * \frac{\left(\% O_{2} T\right)}{\% O_{2}(A r)}\right)} \\
& F_{(P i)}=F_{T}-\left(F_{(A r}+F_{\left(N_{2}\right)}\right) \\
& F_{\mathrm{I}_{\mathrm{C}}}=F_{P i} \cdot \frac{\left(\% \mathrm{I}_{\mathrm{C}}^{\mathrm{C}}\right)}{100} \\
& M_{i_{(G S)}}=\left(\frac{V}{22,4}\right) \cdot M_{(m i)}
\end{aligned}
$$

In order to estimate energy balance, it was used the calorific value at the designed moisture contents equations 7 to II (Energy (MJ) and equations 12 to I4 (Energy balance (\%)), where: $E_{m}$ : wood energy, $I C V_{m}$ : inferior calorific value of wood $\left(\mathrm{M}^{\prime} \cdot \mathrm{kg}^{-1}\right), M_{\mathrm{m}}$ : wood mass, at dry mass $(\mathrm{kg}), E_{c}$ : charcoal energy, $I C V_{c}$ : inferior calorific value of charcoal (MJ. $\left.\mathrm{kg}^{-1}\right), M_{c}$ : charcoal mass, at dry mass $(\mathrm{kg}), I C V_{M \text { J }}$. $\left.{ }_{\mathrm{kgl}}\right)$ : calorific value of gaseous compounds $\left(M J \cdot \mathrm{kg}^{\prime}\right) I C V_{M J}$. ${ }_{\mathrm{Nm} 3} 3$ : calorific value of gaseous compounds $\left(\mathrm{MJ} \cdot \mathrm{Nm}^{-3}\right), \mathrm{M}_{\mathrm{m}}$ : molar mass of the compound $\left(g \cdot \mathrm{mol}^{-1}\right), E_{G S}$ : energy of noncondensable gases $(M J), I C V_{G S}$ : inferior calorific value of non-condensable gases $\left(M J \cdot \mathrm{kg}^{\prime}\right), M_{G S}$ : non-condensable gases mass, at dry mass $(\mathrm{kg}), E_{L P}$ : energy of pyroligneous liquor $(M J), M_{L P}$ : pyroligneous liquor mass, at dry mass $(\mathrm{kg}), \% E_{c}$ : percentage of charcoal energy, $E_{c}$ : charcoal energy $(M J), \% E_{L P}$ : percentage of pyroligneous liquor energy, $E_{L P}:$ pyroligneous liquor energy $(M J), \% E_{G s}$ : percentage of non-condensable gases energy, $E_{G S}$ : noncondensable gases energy $(\mathrm{M})$ ).

$$
\begin{aligned}
& E_{m}=I C V_{m} \cdot M_{m} \\
& E_{c}=I C V_{c} \cdot M_{c} \\
& P C I_{\left.(\mathrm{MJ} \mathrm{kg})^{\prime}\right)}=I C V_{(\mathrm{MJN \textrm {Nm }})} \cdot\left(\frac{22,4}{M_{m}}\right) \\
& E_{(G S)}=I C V_{(G S)} * M_{(G S)} \\
& E_{(L P)} \boxminus 3,592 \cdot M_{(L P)} \\
& \% E_{c}=\left(\frac{E_{c}}{E_{m}}\right) \cdot 100 \\
& \% E_{L P} \boxminus\left(\frac{E_{(L P)}}{E_{m}}\right) \cdot 100 \\
& \% E_{(G S)} \boxminus\left(\frac{E_{(G S)}}{E_{m}}\right) \cdot 100
\end{aligned}
$$




\section{RESULTS AND DISCUSSION}

\section{Mass and Energy balance}

Considering the mass and energy balance, it is possible to verify the outputs yields of charcoal and sub-products after thermochemical conversion of wood. Table I shows the behavior of mass and energy during the pyrolysis process. Additionally, in the Table 2 are registered the mean values of wood and charcoal energy.

Mass balance is essential in the development of new equipments and technologies, mainly to contribute, the dimensional structure calculations, based on the full capacity of production, and the design of the material used, based on diverse parameters such as temperature. Another important factor is to quantify not just the primary products, but also sub-products, which can be incorporated in the system to aggregate value during the process.

TABLE I Mass and energy balance of wood pyrolysis.

\begin{tabular}{ccccc}
\hline & $\begin{array}{c}\text { *Mass } \\
(\mathrm{kg})\end{array}$ & $\begin{array}{c}\text { Yield } \\
(\%)\end{array}$ & $\begin{array}{c}\text { Energy } \\
(\mathrm{MJ})\end{array}$ & $\begin{array}{c}\text { Energy amount } \\
(\%)\end{array}$ \\
\hline \multicolumn{5}{c}{ Material at 0,83\% of moisture content } \\
\hline Wood & 1.903 & \multicolumn{5}{c}{$34,55 \mathrm{I}$} \\
Charcoal & 0.575 & 30.2 & 18.382 & 53.2 \\
Liquor & 0.800 & 42.0 & 2.874 & 8.3 \\
NCG (estimated) & 0.528 & 27.7 & 13.296 & 38.5 \\
Total & \multicolumn{5}{c}{100} & 100 \\
NCG (measured) & 0.331 & 17.4 & 2.549 & 7.4 \\
\hline Total revised & 89.7 & 68.9 \\
\hline \multicolumn{5}{c}{ Material at I3.0\% of moisture content } \\
\hline Wood & 1.937 & 35.665 \\
Charcoal & 0.589 & 30.4 & 18.623 & 52.2 \\
Liquor & 0.900 & 46.5 & 3.233 & 9.1 \\
NCG (estimated) & 0.448 & 23.1 & 13.808 & 38.7 \\
\hline Total & \multicolumn{5}{c}{100} & 100 \\
\hline NCG (measured) & 0.237 & 12.2 & 1.719 & 4.8 \\
\hline Total revised & 89.1 \\
\hline NCG:
\end{tabular}

NCG: non-condensable gases. NCG measured: non-condensable gases measured at gaseous chromatography. *at dry mass.

TABLE 2 Mean values of energetic characterization of wood and charcoal.

\begin{tabular}{ccc}
\hline & Wood & Charcoal \\
\hline Moisture content & $\mathrm{ICV}$ & $\mathrm{ICV}$ \\
$(\%)$ & $\left(\mathrm{MJ} \cdot \mathrm{kg}^{-1}\right)$ & $\left(\mathrm{MJ}^{-1} \mathrm{~kg}^{-1}\right)$ \\
\hline 0.83 & 18.29 & 31.93 \\
13 & 18.37 & 31.25 \\
\hline
\end{tabular}

ICV: inferior calorific value.

According to Wei et al. (20II), mass balance displays a consistent theoretical base regarding the decision-making on investments and to reduce manufacturing costs. The analysis used balance equations, in which is considered the several generated products during the pyrolysis process. However, there is still not enough information available about all pyrolysis products yields when considering similar results achieved at industrial scale. Hence, in this present work, it was performed analysis based on larger specimens, in which the dimensions of them try to simulate, at least experimentally, what happens at a large-scale charcoal production in Brazil.

Charcoal yields (30.2 and $30.4 \%$ for 0.83 and $13 \%$ moisture content, respectively) of the experimented materials have been poorly influenced by the moisture contents. In general, moisture contents lower than II\% has low influence in the final charcoal yield (Chan et. al., 1985; Di Blasi et al., 2000; Valente; Lilles, 1986). High initial moisture content of wood e.g. $>30 \%$, can cause a slow heating rates and consequently, the devolatilization of the charcoal turns into an incomplete process, which reflects in gravimetric yields lower than $30 \%$, characteristic that is not desirable by charcoal industries. According to Arruda (20II), the gravimetric charcoal yields are usually low, about $23.8 \%$ or $28.4 \%$, when it is used raw materials with elevated moisture contents, such as $66 \%$ and $48 \%$, respectively.

In the condensable fraction of pyrolysis, it was obtained $42 \%$ and $46.5 \%$ of yield (Table 3 ). It is assumed that the water inside of the wood is responsible for the greatest portion and composition of the pyroligneous acid. The higher the moisture content, the higher is the production of liquor yield. According to Ferreira (2000), almost $100 \%$ of the water contained in the wood is part of the composition of the pyroligneous liquor.

TABLE 3 Masses of the principal gaseous compounds produced in the pyrolysis process.

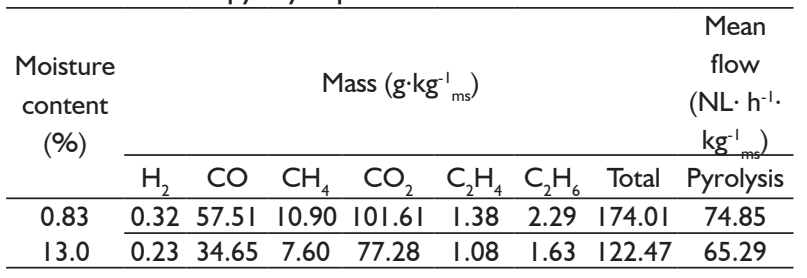

$\mathrm{H}_{2}$ : hydrogen; $\mathrm{CO}$ : carbon monoxide; $\mathrm{CH}_{4}$ : methane; $\mathrm{CO}_{2}$ : carbon dioxide; $\mathrm{C}_{2} \mathrm{H}_{4}$ : ethylene; $\mathrm{C}_{2} \mathrm{H}_{6}$ : ethane; $\mathrm{NL} \cdot \mathrm{h}^{-1} \cdot \mathrm{kg}^{-1}{ }_{\mathrm{ms}}:$ Normal liter/hour/kilogram of dry mass.

However, a possible moisture effect during the dilution of the NCG (measured) can be visualized in the gases energy values (Table 4). Wood sample with $0.83 \%$ of initial moisture content produced $6 \%$ more energetic value compared with $13 \%$ of initial moisture content, during the pyrolysis of NCG (measured). Water presence into the wood can influence the dissolution degree of gases emitted during pyrolysis, which means a reduction in its concentration and also affecting the total energy released.

Nearly $53 \%$ of the total energy in the process is concentrated in charcoal and $46 \%$ remains in the sub-products (Table 3). Indeed, sub-products are 
TABLE 4 Distribution of non-condensable gases yield in energetic and non-energetic gases of pyrolysis.

\begin{tabular}{ccc}
\hline $\begin{array}{c}\text { Moisture content } \\
(\%)\end{array}$ & $\begin{array}{c}\text { Energetic gases } \\
(\%)\end{array}$ & $\begin{array}{c}\text { Non-energetic } \\
\text { gases (\%) }\end{array}$ \\
\hline 0,83 & 41,60 & 58,40 \\
13,0 & 36,90 & 63,10 \\
\hline
\end{tabular}

$\mathrm{m} \cdot \mathrm{m}^{-1}:$ mass by mass.

poorly reused in most of the pyrolysis systems, mainly because of the low-level technology employed in the charcoal industries. There are also energetic losses in the conversion system itself, such as endothermic and exothermic reactions, which happens during the process. This kind of losses are not considered when it is calculated the mass and energy balance. However, according to Raad et al. (2006) they are unavoidable during thermal decomposition of wood.

Mass and energy of non-condensable gases (NCG measured)

There were identified six chemical compounds during the process: hydrogen gas $\left(\mathrm{H}_{2}\right)$, carbon monoxide (CO), methane $\left(\mathrm{CH}_{4}\right)$, carbon dioxide $\left(\mathrm{CO}_{2}\right)$, ethylene $\left(\mathrm{C}_{2} \mathrm{H}_{4}\right)$ and ethane $\left(\mathrm{C}_{2} \mathrm{H}_{6}\right)$ (Table 3 and Figure 2). The highest gas emission was $\mathrm{CO}_{2}$, and the lowest was $\mathrm{H}_{2}$.

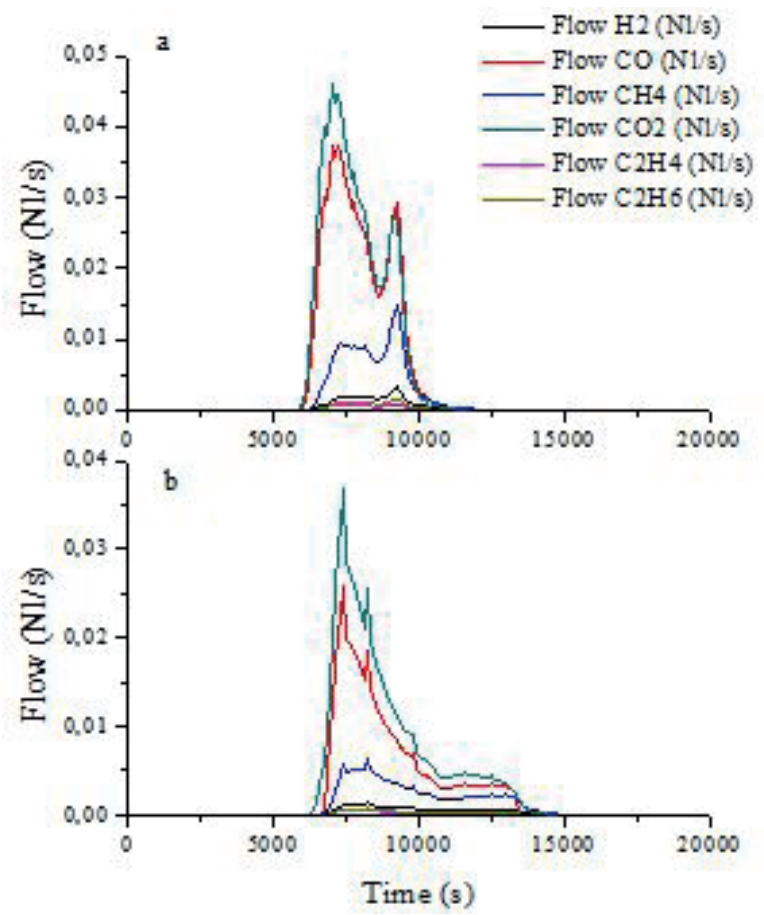

FIGURE 2 Gas flow of wood pyrolysis at (a) - 13\% moisture content, and (b) $-0.83 \%$ moisture content.

Table 4 shows the gases energy values. Considering the wood pyrolysis at $0.83 \%$ moisture content, it was produced $41.6 \%$ of energetic gases, such as $\mathrm{H}_{2}, \mathrm{CO}, \mathrm{CH}_{4}$, $\mathrm{C}_{2} \mathrm{H}_{4}$ e $\mathrm{C}_{2} \mathrm{H}_{6}$. For wood pyrolysis at $13 \%$ of moisture content, it was produced just $36 \%$ of energetic gases. Non-energetic gases represent more than $50 \%$ of the gaseous compounds emitted during pyrolysis.

In Figure 2 can be observe the compounds flow $\left(\mathrm{H}_{2}\right.$, $\mathrm{CO}, \mathrm{CH}_{4}, \mathrm{CO}_{2}, \mathrm{C}_{2} \mathrm{H}_{4}$ and $\mathrm{C}_{2} \mathrm{H}_{6}$ ) during the pyrolysis process of wood. After 120 minutes of pyrolysis ignition, the gas production increase, keeping this rate for about 30 minutes.

The difference in the pyrolysis flux (74.85 and $\left.65.39 \mathrm{NL} \cdot \mathrm{h}^{-1} \cdot \mathrm{kg}^{-1}{ }_{\mathrm{ms}}\right)$ of the materials is associated with their initial moisture content $(0.83 \%$ and $13.0 \%)$. Wood thermal decomposition increase the release of the bound water, which may cause a decrease in the total flow of gaseous compounds. Table 4 reports that the energetic gases concentration on the pyrolysis of the wood is higher at lower moisture content. Indeed, it shows the effect of water inside the wood considering the production of gases compounds during the pyrolysis process. The presence of water can cause the dilution of the gases and consequently affect the total energy of the pyrolysis. The difference between both energy balances with NCG (measured) shows that the initial moisture content of the wood influences the energetic concentration.

The gaseous compounds flow (Figure 2) increase at 120 minutes after pyrolysis ignition. This behavior is related to the depolymerization of structural compounds of wood, mainly cellulose and lignin (Jesus et al., 2015; Pinheiro et al., 2005; Zeng et al., 2015). This interval range of gas production may also be associated with the chemical transformation of cellulose, being the primary chemical constituent of wood (Anca-Couce, 2016; Yang et al., 2007; Kan et al., 20I6; Wang et al., 20I7).

At temperatures below $600^{\circ} \mathrm{C}, \mathrm{H}_{2}$ is little produced and lignin becomes the main compound responsible for the formation of $\mathrm{H}_{2}$ (Amutio et al., 2012). Emissions of $\mathrm{CO}$ and $\mathrm{CO}_{2}$ are related to the releases of the groups present in the hemicelluloses $(\mathrm{C}=\mathrm{O}, \mathrm{C}-\mathrm{O}, \mathrm{C}-\mathrm{C})$ and in the linear polymer chain of cellulose. Furthermore, $\mathrm{CO}_{2}$ formation is associated with the chemical reactions of decarboxylation and depolymerization, which occur during the secondary reactions of volatile materials (Balat, 2008; Yang et al., 2007; Lin et al., 2009).

\section{Thermogravimetric analysis in macro-lab scale}

Based on thermogravimetric analysis it was identified the temperatures in which the wood had the highest mass loss during the pyrolysis process. At $280^{\circ} \mathrm{C}$ thermal decomposition is more perceptible for the samples containing $0.83 \%$ moisture content. For the sample at $13 \%$ of moisture content, thermal decomposition was raise after reaching $380^{\circ} \mathrm{C}$ (Figure 3 e Figure 4). 


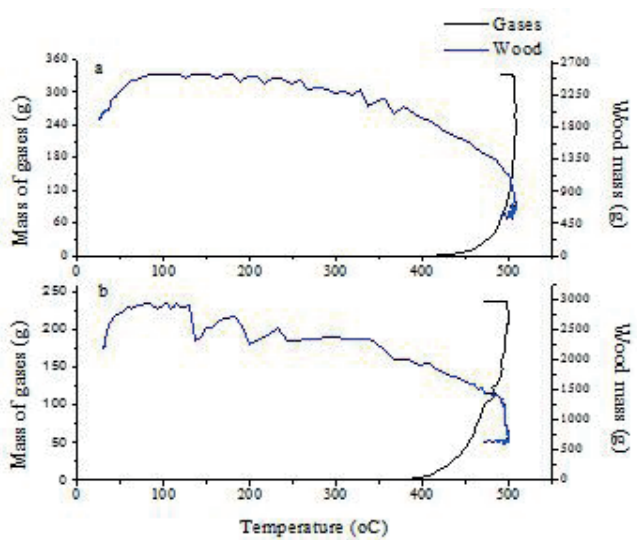

FIGURE 3 Macro ATG analysis of wood and non-condensable gases during pyrolysis regarding temperature increments at (a) - 13\% of moisture content, and (b) $0.83 \%$ of moisture content.
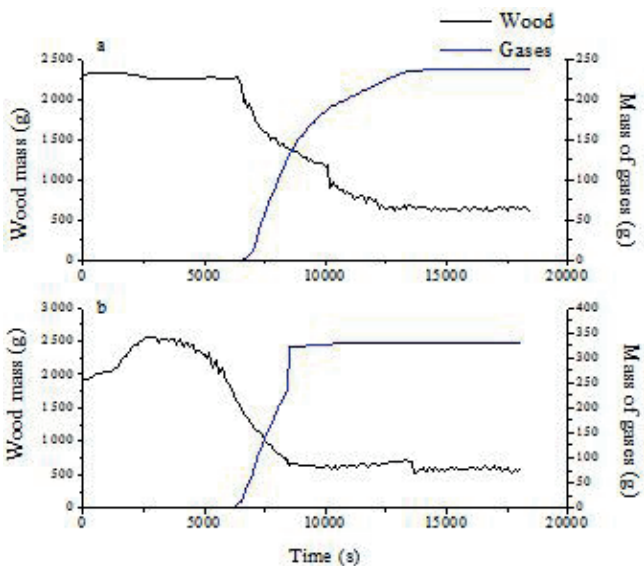

FIGURE 4 Macro ATG analysis of wood and non-condensable gases during pyrolysis regarding time increments (a) $-0.83 \%$ of moisture content, and (b) $-13 \%$ of moisture content.

Regarding thermaldecomposition of thewood, dueto the supply of increasing temperatures, a thermogravimetric analysis was also carried out. The difference between the treatments of the temperature during the wood thermal decomposition was $100^{\circ} \mathrm{C}$, considering the higher influence of heat transfer in the material with low moisture content (Figure 3). Simultaneously, chemical reactions occur after wood drying, as a result of the heat and mass transfer. Therefore, higher moisture content in the sample center region tends to concentrate significant amount of water. Thus, during the heating process, high temperature and energetic waste increase, and consequently, the thermal conversion of wood into charcoal decrease (Hasan et al., 2017; Missio et al., 20I4).

\section{Perspectives}

In Brazil, the siderurgy sector uses significant amounts of charcoal to produce steel. Its large integrated factories and forest plantations, support the high development of the charcoal production and forest maintenance. Brazil stands out internationally in the iron market, being the only country that uses renewable raw material, unlike its competitors that use coke (nonrenewable fuel with high polluting capacity). Currently, the major challenge facing the Brazilian forestry sector, especially in the charcoal area, is to develop technologies to understand the process on a scale similar to those used in large-scale production units, as well as to generate new industrial mechanisms to improve yield and quality of value-added product. Particularly, within the industrial reality where carbonization of significant volumes of wood occurs at relatively low rates, and the difficulty on the implementation of raw materials because parameters such as variable features and large dimensions. As can be seen in Table 3, in the final pyrolysis balance, besides the charcoal, there are also sub-products with high energetic potential, especially considering the gaseous compounds. Therefore, it is relevant to study the gases flow, especially in Brazil, which does not have a defined burning mechanism yet. From this work, it is suggested to consider the mass balance and flow of energy compounds in further researches of integration and optimization of technologies in both, production and gas burning process, aiming to support the prospects of integrating the productive chain of charcoal.

\section{CONCLUSIONS}

This study aimed to understand the mass and energy balance of large cylindrical specimens, which resemble those used in the Brazilian charcoal production units. The process was carried out using an innovative pyrolysis technology, the Macro ATG oven, in which it was verified how the moisture contents ( 0.83 and $13 \%)$ influenced the mass and energy balance of the process, as well as the gas production and quality. It was observed the poor effect of the moisture in the mass and energy balance during the complete process.

The presence of water inside the wood influenced the degree of dissolution of the gases emitted during pyrolysis, which reduced its concentration, flow and affected the total energy released.

There was a higher heat/energy demand in the thermal decomposition of the higher moisture content material.

An amount of $53 \%$ of the total energy of the process was concentrated in the main product (charcoal), whereas the other $47 \%$ of the remaining energy is concentrated in sub products.

The gas production peak begins I 20 minutes after pyrolysis ignition. Meaning that this is probably the best period for burning gases. 


\section{ACKNOWLEDGMENT}

The author expresses your special thanks to the Center of International Cooperation in Agronomic Research for Development (UPR of CIRAD, Montpellier, France) and also to the Department of Forest Sciences Wood Science and Technology of the Federal University of Lavras (UFLA, Brazil). This study was financially supported by CNPq (National Council for Scientific and Technological Development, Brazil), CAPES (Higher Education Personnel Improvement Coordination, Brazil) and FAPEMIG (Foundation for Research Support of the State of Minas Gerais, Brazil).

\section{REFERENCES}

AMUTIO, M.; LOPEZ, G.; ARTETXE, M.; ELORDI, G.; OLAZAR, M.; BILBAO, J. Influence of temperature on biomass pyrolysis in a conical spouted bed reactor. Resources, Conservation and Recycling, v. 59, n. I, p. 23-31, 2012.

ANCA-COUCE, A. Reaction mechanisms and multi-scale modelling of lignocellulosic biomass pyrolysis. Progress in Energy and Combustion Science, v.53, p. 4I-79, 2016.

ARRUDA, T. P. M.; PIMENTA, A.S.; VITAL, B.R.; LUCIA, R.M.D.; ACOSTA, F.C. Avaliação de duas rotinas de carbonização em fornos retangulares. Revista Árvore, Viçosa, v.35, n.4, p.949-955, 2011 .

BALAT, M. Mechanisms of thermochemical biomass conversion processes. Part I: reactions of pyrolysis. Energy Sources, Part A, v. 30, n.7, p. 620-635, 2008.

BARCELLOS, D. C.; VITAL, B. R. ; SILVA, J. S.; PIMENTA, A. S.; COUTO, L. C. Cellular Furnace as a Pollution and energy generation control source in carbonization using container oven. Biomassa \& Energia,v. I, p. 335-342, 2004.

CHAN, W. C. R.; KELBON, M.; KRIEGER, B. B. Modelling and experimental verification of physical and chemical processes during pyrolysis of a large biomass particle, Fuel, v.64, n.I, p. I505-1513, 1985.

DI BLASI, C.; HERNANDEZ, E. G.; SANTORO, A. Radiative pyrolysis of single moist wood particles. Industrial \& Engineering Chemistry Research. v. 39, n. I, 873-882, 2000.

ERNSTING, A. Biomass gasification \& pyrolysis: how UK support for energy innovation' leads to business failures and particularly inefficient and dirty biomass power stations. United Kingdom: [s.n.], 2015. 4 I p.

FERREIRA, O. C. 2000. Emissions of greenhouse gases in the production and use of plant charcoal. Revista Economia \& Energia, v.I, n.I, p.I-I6.

FOA, Food and agriculture organization of the united nations. Statistical data bases:FAOSTAT-Forestry. Rome: FAO, 2013. Disponível em: <http://www.faostat.fao.org/faostat>.

HASAN, M. M., HU, X., GUNAWAN, R.; LI, C. Z. (2017). Pyrolysis of large mallee wood particles: Temperature gradients within a pyrolysing particle and effects of moisture content. FuelProcessing Technology, v. I58, p.I63-I7I.
INDÚSTRIA BRASILEIRADEÁRVORES. Associação que representa os segmentos de painéis e pisos de madeira, celulose, papel e florestas energéticas. Brasília: IBÁ, 2016. 100 p.

International Energy Agency Energy Database, <http://www. worldenergyoutlook.org/resources/energydevelopment/ energyaccessdatabase/>, acess in May, 2017.

JESUS, M. S.; NAPOLI, A.; ANDRADE, F.W. C.; TRUGILHO, P. F.; ROCHA, M. F. V.; GALLET, P.; BOUTAHAR, N. Macro ATG Kiln: gaseous flow study in the pyrolysis process of Eucalyptus. Ciência da Madeira, v.6, n.I, p. 269-274, 2015.

KAN, T.; STREZOV, V.; EVANS, T. J. (20I6). Lignocellulosic biomass pyrolysis: A review of product properties and effects of pyrolysis parameters. Renewable and Sustainable Energy Reviews, v. 57, p. I I 26- I I 40.

LIN, Y. C., CHO, J., TOMPSETT, G. A., WESTMORELAND, P. R., HUBER, G. W. Kinetics and mechanism of cellulose pyrolysis. The Journal of Physical Chemistry C, v. I I3, n.46, p.20097-20107, 2009.

MISSIO, A. L.; MATTOS, B. D.; GATTO, D. A.; LIMA, E. A. Thermal analysis of charcoal from fast- growing eucalypt wood: influence of raw material moisture content. Journal of Wood Chemistry and Technology, v.34, n. I, p. I9I-20I, 2014.

PEREIRA, E. G., MARTINS, M. A., PECENKA, R., ANGÉLICA DE CÁSSIA, O. C. Pyrolysis gases burners: Sustainability for integrated production of charcoal, heat and electricity. Renewable and Sustainable Energy Reviews, v.75, p. 592-600, 2017.

PINHEIRO, P. C. C.; FIGUEIREDO, F. J.; SEYE, O. Influence of temperature and carbonization heating rate on the properties of eucalyptus charcoal Eucalyptus. Biomassa \& Energia, v.2, n. I, p. I59-168, 2005.

RAAD, T. J.; PINHEIRO, P. C. C.; YOSHIDA, M. I. General equation of kinetic mechanisms of Eucalyptus carbonization Eucalyptus. Cerne, v. I2, p. 93-106, 2006.

VALENTE, A. F; LELLES, J. G. Carbonization of Eucalyptus wood. Informe Agropecuário, v. I 2, n. I, p.74-79, 1986.

WEI, Q.; QU, Y.; TAN, T. Mass and heat balance calculations and economic evaluation of an innovative biomass pyrolysis project. Frontiers of Chemical Science and Engineering, v.5, n. I, p.355-36I, $201 \mathrm{l}$.

YANG, H.; YAN, R.; CHEN, H.; LEE, D. H.; ZHENG, C. Characteristics of hemicellulose, cellulose and lignin pyrolysis. Fuel, v.86, n.I, p.I78I-I788, 2007.

ZENG, K.; MINH, D. P.; GAUTHIER, D.; WEISS-HORTALA, E.; NZIHOU, A.; FLAMANT, G.The effect of temperature and heating rate on char properties obtained from solar pyrolysis of beech wood. Bioresource Technology, v. I82, n. I, II4-II9, 2015.

WANG, S., DAI, G., YANG, H., LUO, Z. Lignocellulosic biomass pyrolysis mechanism: A state-of-the-art review. Progress in Energy and Combustion Science, v..62, p.33-86, 2017. 